\title{
Bad for Party Discipline: Why Unions Attacked the Single Transferable Vote in Cincinnati*
}

\author{
Jack Santucci \\ jack@voteguy.com \\ This version: June 28, 2017 \\ Original: July 22, 2015
}

The years around World War I brought major political changes to advanced industrial democracies. New demands led to rapid extensions of voting rights, mass defections to laborbased parties, and the adoption of proportional representation (PR) voting schemes. ${ }^{1}$ The last of these is the most important cause of a multi-party system. ${ }^{2}$ Roughly speaking, if a party gets ten percent of votes, it gets ten percent of legislative seats. Political scientists have long observed that social democracy thrives under PR. ${ }^{3}$ Oftentimes, as in Australia, Germany, and Switzerland, local PR experiments predated a national adoption. ${ }^{4}$

The United States was not immune to the global changes in party systems. Women won the vote in 1920, officially doubling electorates in states that had not yet granted voting rights. ${ }^{5}$ Third-party presidential runs in 1912 and 1924 shook the Republican Party in the Mountain States and American Midwest. This intra-party fighting continued in cities where reformers rewrote voting rules to eject the old-style parties from power. ${ }^{6}$ From $1915-48$, in fact, the chosen reform in 24 cities was proportional representation.

*Jasmine Underwood provided research assistance. Bill Collins, Jack Lucas, Colin Moore, Hans Noel, Rob Richie, and Kent Weaver gave helpful feedback on earlier drafts. Bill Gradison gave important insight into local history. 
Compared to PR systems in other countries, however, the American version was hostile to parties. Having negotiated with the movement for non-partisan elections, the American PR League in 1914 settled on a radically candidate-centered form of local democracy: councilmanager government, a council of seven or nine members, nomination by petition, party-free ballots, and PR via the single transferable vote (known today as "multi-winner ranked-choice voting").${ }^{7}$ In theory, any lone candidate with the requisite signatures and ten percent of votes citywide could win, resulting in a council without stable voting blocks.

On adopting PR in 1924, Cincinnati appeared to have solved the problem of coalition stability. The fix would be a pre-election deal between two groups formerly out of power: incumbent-party defectors and the local minority party. These groups would present a common slate, then ask voters to vote for the whole slate. Those groups in Cincinnati were Progressive Republicans and the Democratic Party, jointly known as the Charter Party. With the help of Cincinnati politician Charles Phelps Taft II, the National Municipal League exported this model to 17 more cities in Ohio, Oregon, Massachusetts, New York, and Tennessee. $^{8}$

Beginning in the 1930s, however, a sequence of ballot initiatives restored plurality voting, such that only Cambridge (MA) retained PR by 1962. The standard explanation is that PR empowered leftists and black political leaders in a period of unusual social conservatism. ${ }^{9}$ This account rests heavily on New York City, where Communist Party member Benjamin Davis won election in 1945, and Cincinnati, where Theodore "Ted" Berry nearly became the city's first black mayor in $1955 .{ }^{10}$ Some argue these figures so soured public opinion on PR that aging reformers simply lost interest in defending it. ${ }^{11}$

The standard explanation raises several questions. How should we explain the end of 
PR in six of seven Massachusetts cities, which generated no figures like Berry nor Davis? Further, how can we account for the absence of repeal in the presence of earlier such figures? ${ }^{12}$ Why did New Yorkers not repeal PR in 1941, when Adam Clayton Powell, Jr. represented the American Labor Party, nor in 1943, when Pete Cacchione of the Communist Party won election to council? Why did Cincinnati not repeal PR when Jesse Locker spoke for blacks in the late 1940s, nor when Frank A.B. Hall won election in the late 1920s? Finally, if a loss of reformer energy explains the end of PR, efforts to repeal it must have been continuous. They were not. ${ }^{13}$

This essay returns to Cincinnati, one major source of conventional wisdom, in order to test a different explanation. Candidate-centered PR elections pose a risk that disciplined party systems do not: different majorities for different types of legislation. When majorities become ad hoc, a powerful interest group can lose on an issue it feels important. In mid1950s Cincinnati, that is what happened to Democrats from the Congress of Industrial Organizations (CIO). Their Progressive Republican coalition partners began to take antilabor positions in government. No less than the national director of AFL-CIO's Industrial Union Department intervened on Democrats' behalf. His agent in Cincinnati was the United Steelworkers of America.

The article proceeds as follows. I begin with an explanation of the single transferable vote (STV) as applied in American local government, focusing on its specific threat to legislative discipline. Then I give a short case overview from PR's inception in 1924 to its stormy repeal in 1957. Four subsequent sections trace the major bargains on Cincinnati City Council in four key periods: the late Progressive Era, labor's New Deal rise, regular Republicans' postwar rejection of labor, and middle-class liberals' 1950s takeover of Charter. A final section 
sketches implications for the modern election reform lobby. Any current effort to restore PR voting ought to find ways to bolster legislative discipline.

\section{How the PR charter might diminish party discipline}

Across American cities, two aspects of the model charter deprived party leaders of the means to enforce legislative discipline. One was nomination by petition (also called the open endorsement). ${ }^{14}$ Another was the ability of individually popular candidates to direct "surplus" votes to chosen allies. To understand how this worked, we need to contrast the PR charter with other forms of proportional voting.

All forms of PR involve the construction of candidate lists. At the broadest level, each seat in a district corresponds to some share of the vote. Say that share is ten percent. If a list earns thirty percent of votes, it gets three seats - one for each of its tenths of the vote. The candidates who get those seats are the top three on the list. It follows that every candidate's goal is to be near the top of a list. Party leaders know this, so the price of list position is loyalty to leaders.

Forms of PR vary in terms of leader control over list position. In the extreme, voters choose only among parties, and party leaders have exclusive control of list order. Known as the "closed list," this PR method was rare at the time of the model charter's development.

Two other methods received significant attention before 1914, and both might better have empowered party leaders to enforce discipline. The Gove system would have let each candidate propose their own list, and a vote for a candidate was a vote for the list. Assuming party leaders could draw up the most popular lists, votes would flow only to same-party 
candidates. At the same time, a so-called "free list" system corresponded to what we now know as open-list PR. Each party would present its own list. While voters would be free to alter the order of that list, they would not be able to split their tickets. As it turned out, weak prospects for ticket splitting was the non-partisan movement's main reason for opposing the Gove and free-list systems. ${ }^{15}$

What reformers chose instead was the single transferable vote (STV). STV lets voters rank all candidates at once, regardless of party affiliation. Every seat corresponds to some share of the vote, as in other forms of PR. ${ }^{16}$ Candidates with votes in excess of the victory share can direct this "surplus" to other candidates of choice, so long as voters follow their instructions. Where do surplus votes end up? It depends on how voters have ranked their ballots.

With STV, if a substantial number of voters were distributing their rankings across party lines, the entire idea of a party list became meaningless. Further, in contrast with the Gove system - again, this allowed each candidate to propose their own list - a single candidate could send some of their surplus to one group of candidates, some of it to another group, and so on.

From the perspective of empowering party leaders, one solution would have been some means of keeping disloyal candidates off the ballot. The model charter did not contain one. Nomination was to be strictly by petition. In Cincinnati, a candidate needed 800 signatures to be on the ballot. In New York City, the figure was 2,000. In some Massachusetts cities, a candidate needed only 50 signatures.

Fortunately for parties, non-partisan ballots meant that open-endorsement STV elections were low-information affairs. Voters would have no markers to use in deciding their rankings 
other than incumbency, co-ethnicity, and whatever else might be inferred from a name (and possibly a residential address). This meant that well-provisioned groups (such as parties) could present their slates, flood the news with information on those slates, and organize get-out-the-vote drives as necessary. Figure 1 shows how Cincinnati's Charter Party used this strategy in 1951. All at once, the pamphlet emphasizes candidates' personal accolades and asks voters to vote for every candidate.

On the other hand, nomination by petition meant that whatever parties existed - be they old parties, new parties, or formal coalitions like Charter - would be penetrable by independents. Candidates would gradually build their own support bases, possibly by running unsuccessfully in one or more elections, eventually inducing a party to slate them. Why would the party slate them? It needed their surplus votes for the rest of the slate.

Open-endorsement STV therefore reversed the usual PR relationship between parties and candidates. Under normal PR, parties use list position to discipline their deputies. With the model PR charter, vote-seeking parties sometimes chased popular independent candidates. That meant nominating a special type of candidate: one with surplus votes to share with the rest of the party. But nothing ensured that candidate would share their votes as planned. And in the extreme, an STV slate might contain many such candidates. That did not guarantee poor party discipline, but it also did not deter it.

\section{From Progressive reform to labor reaction, 1924-57}

The [repeal of PR] would put an end to block-voting and bigotry and return Council to party responsibility. 


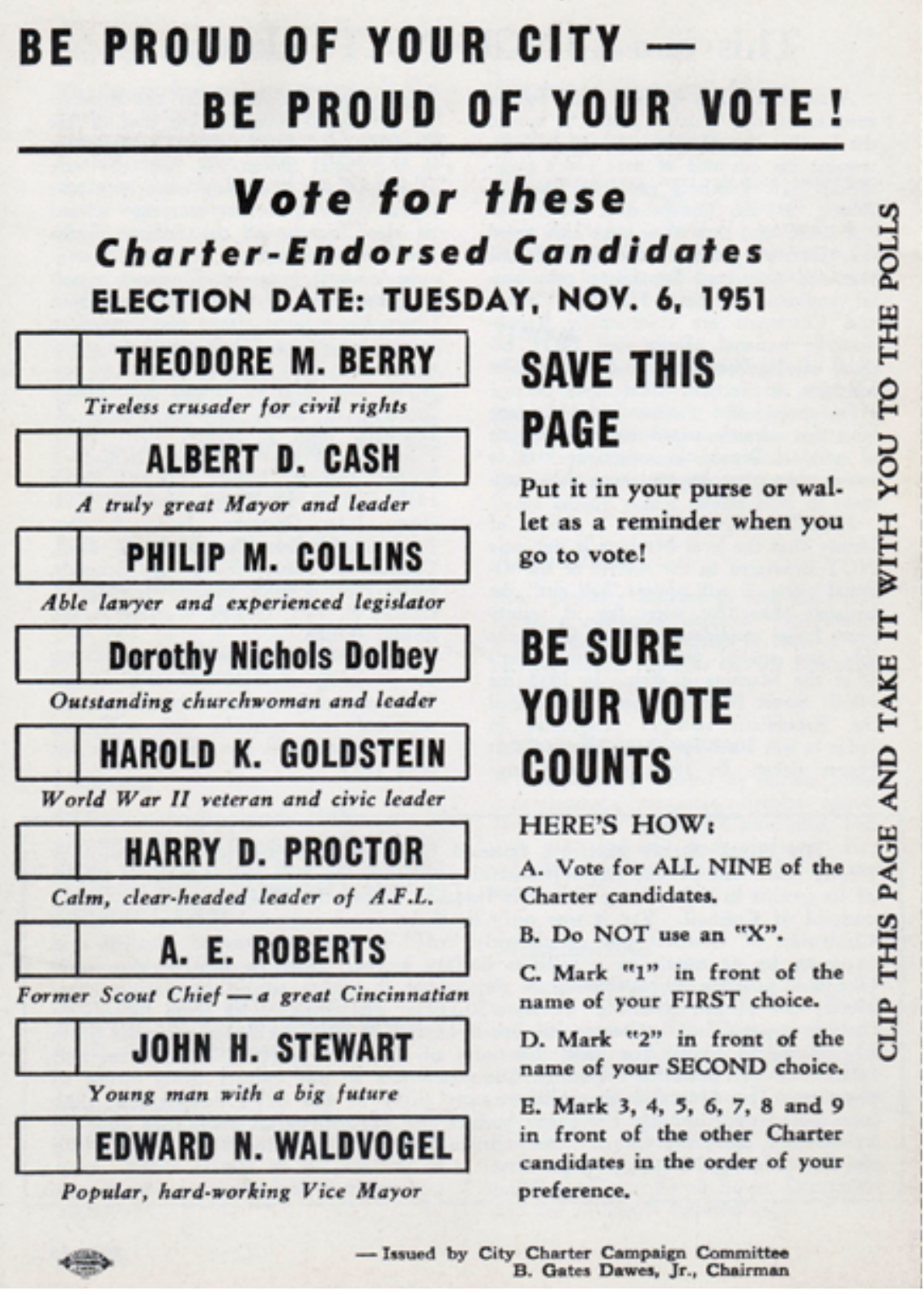

Figure 1: Charter Party how-to-vote pamphlet from the 1951 Cincinnati Council elections. Source: http://www. chartercommittee.org. 
- Democratic co-organizer of the campaign to repeal PR, $1954 .{ }^{17}$

In 1924, Cincinnati voters approved a city-manager charter. It called for nonpartisan elections to a council of nine. As in no less than fifteen other cities, defectors from the incumbent party conceded PR elections to win referendum support from the local minority party. ${ }^{18}$ The players in Cincinnati were three: regular Republicans from the local party "machine," out-of-power Democrats, and a faction of defecting Progressive Republicans. The latter two groups formed the Charter Party, which ran a full slate in every election thereafter. ${ }^{19}$ There ensued five efforts to repeal PR. Labor opposed the first four. ${ }^{20}$

Repeal finally won in 1957 by 11,000 votes. According to reports on the eve of the referendum, "Republicans have attracted the support of the United Steel Workers, numbering about 15,000 Cincinnatians, which previously backed PR." ${ }^{21}$ The campaign was notable for racist rhetoric, especially rumors that Theodore Berry might become mayor. Other rumors had the Democratic NAACP leader buying a home in a "white neighborhood." ${ }^{22}$ What makes this puzzling is the CIO's championship, in Ohio and elsewhere, of racial liberalism in the Democratic Party. ${ }^{23}$ Stranger still, I show below that Berry and the CIO were on the same sides of both desegregation and collective bargaining controversies. The Republicans that the CIO colluded with were not. How can we account for this behavior?

The answer is that labor Democrats had forged a New Deal-style developmental bargain with business interests in the local Republican Party. Republicans abrogated this working arrangement in the late 1940s and early 1950s. By 1955, middle-class liberals had seized control of Charter, forcing Berry and the unions to search for new allies. One of the liberals, 
Dorothy N. Dolbey, was Republican in national politics and refused to vote for pro-labor bills. Facing a new break between race and labor liberalism, Berry sided with Dolbey. His support for her mayoral bid and 1955 re-election campaign explain the racial animus at play.

We therefore can identify four major periods in Cincinnati's PR experience. Each corresponds to a coalition alignment in city council:

1. A Progressive-era alliance between Democrats and the Republican reformers;

2. A New Deal working arrangement between labor Democrats and regular Republicans;

3. A McCarthy-era rejection of the unions by Republicans;

4. And a Democratic-reform Republican coalition of modern racial liberals.

The sections that follow discuss each period in detail. Before proceeding to the period descriptions, we can get a sense of the shifting coalitions from patterns in the transfer of votes among parties. Recall that popular candidates in STV elections have surplus votes to share. ${ }^{24}$ Panels in the plot below illustrate two sets of patterns. ${ }^{25}$ On the left, we see the rates at which each of three groups sent votes to the regular Republican Party: regular Republicans themselves, then Charter's two component groups (the Democrats and Progressive Republicans). On the right, we see the rates at which Charter's component groups kept votes within the coalition.

Three big trends stand out in each panel. First, Democrats and Charter Republicans are best at keeping votes within the coalition during the Charter Party's earliest years. Then, beginning in the mid-1930s, Democrats send increasing volumes of votes to regular Republicans, at the expense of the Charter coalition. Then, in the late 1940s-early 1950s, 

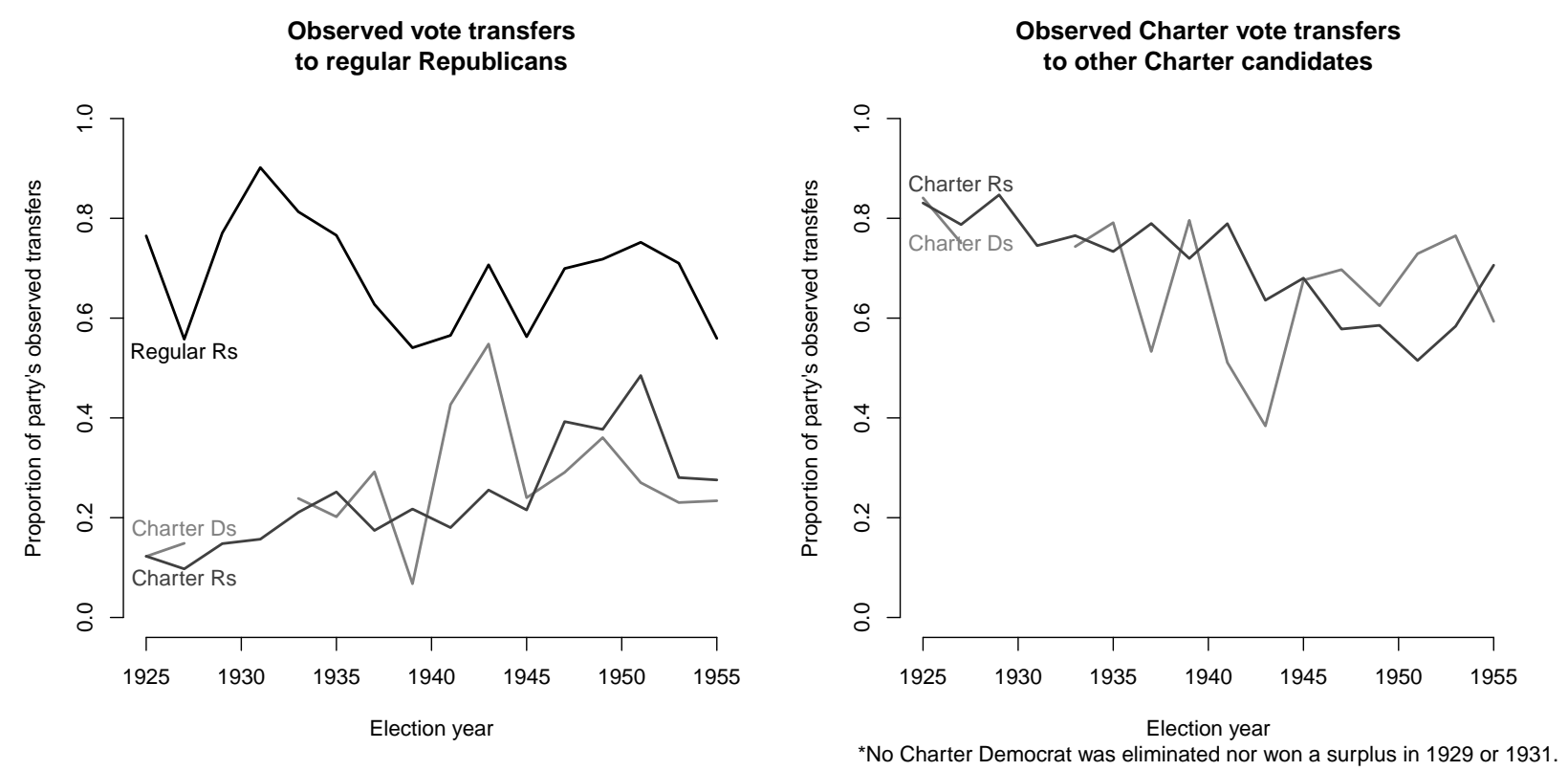

Figure 2: How votes flowed among the three key factions as a result of STV elections.

Charter Republicans begin sending votes to the opposing party. The case history to follow explains why we see these trends.

\section{From Progressive Reform to the 1930s}

Urban institutional reform was a middle-class project, and early PR in Cincinnati was no exception. ${ }^{26}$ The size of the PR council was an immediate point of disagreement, with Democrats and trade unionists preferring a 25 -seat body elected from several multi-member districts. Notable among these was Herbert Bigelow, a member of Robert M. LaFolette's left-wing Conference for Progressive Political Action and eventual U.S. Representative (DOH, 1937-9). The Republican defectors preferred a small, at-large council to prevent the emergence of "racial, geographical, religious, and other blocks." Democrats capitulated to insistence on the small council. ${ }^{27}$ 
PR's relationship to racial and ethnic diversity was mixed. On the one hand, it left groups outside the party system an opportunity to mount their own candidacies. On the other hand, it did not stop parties from forming to influence the nomination process. PR's most detailed historian writes that at least two candidates had hate-group connections in its 32-year history. One was a 1925 Charter winner with Ku Klux Klan endorsement. Yet another was a Republican who "flirted with groups which displayed the Swastika and sang the Horst Wessel song." 28 African-American leaders appear to have had mixed feelings. While the most heavily black wards voted against PR in 1924, the local black newspaper and Marcus Garvey's Universal Negro Improvement Association supported it. ${ }^{29}$ African Americans mounted independent candidacies as early as 1927, but none would gain (Republican) party endorsement (and election) until 1931. ${ }^{30}$

One of the council's first acts was a zoning law to buttress property values in growing suburbs. Before 1925, Republicans' hands-off policy had led to racial and class diversity in some outlying neighborhoods. A typical pattern involved poorer residents building or renting large, multi-family homes, often following more wealthy co-ethnics who had moved there before. Legislation in 1925 banned multi-unit construction in most suburbs, laying the groundwork for residential segregation that would peak in $1950 .{ }^{31}$ This provoked immediate reaction. In 1927, a building association president won election as chairman of the More Homes Campaign, reducing Charter's majority to 5-3-1. ${ }^{32}$ 


\section{Labor forces accommodation: New Deal and the 1940s}

PR's first challenge came in 1936, when repeal lost by only 797 votes (1.1 percentage points). A second repeal attempt in 1939 failed by 767 votes (0.8 percentage points). The prevailing account of these efforts centers on Herbert Bigelow and his Progressive Democratic (PD) party. According to conventional wisdom, elections in 1935 and 1937 returned "hung" 4-4-1 councils, forcing the parties to bargain for mayoral support. Charter concessions in 1936 so alienated the business community - municipal ownership of utilities and adoption of a single tax - that some Republicans left the coalition. Regular Republicans were unwilling to make these concessions. To avoid another deal in 1938, Republican Charter member

Charles P. Taft rolled his own party to support the opposing mayoral pick. ${ }^{33}$ The forces of redistribution appeared to have weakened Charter, with Republicans emboldened enough to gamble on repeal. Twice the Republicans miscalculated.

Transfer votes suggest another interpretation of the failed PR repeal attempts of 1936 and 1939. Perhaps these were efforts to create a different working majority. Some support for this exists in the preference flows of PD voters. Figure 3 gives the destinations of vote transfers from Bigelow faction ballots. In these elections, observed PD transfers favored Republican candidates over Charter Democrats by 10-20 percentage points, then Republicans over Charter Republicans by 30-50 percentage points. All of this suggests the modal PD voter wanted their vote to go to Progressive Democrats first, then regular Republicans, then regular Democrats, then the Charter Republicans.

Historiography suggests that labor dissatisfaction with Charter extended back to 1931, when "certain labor elements plus disgruntled Democrats unhappy about the patronage 


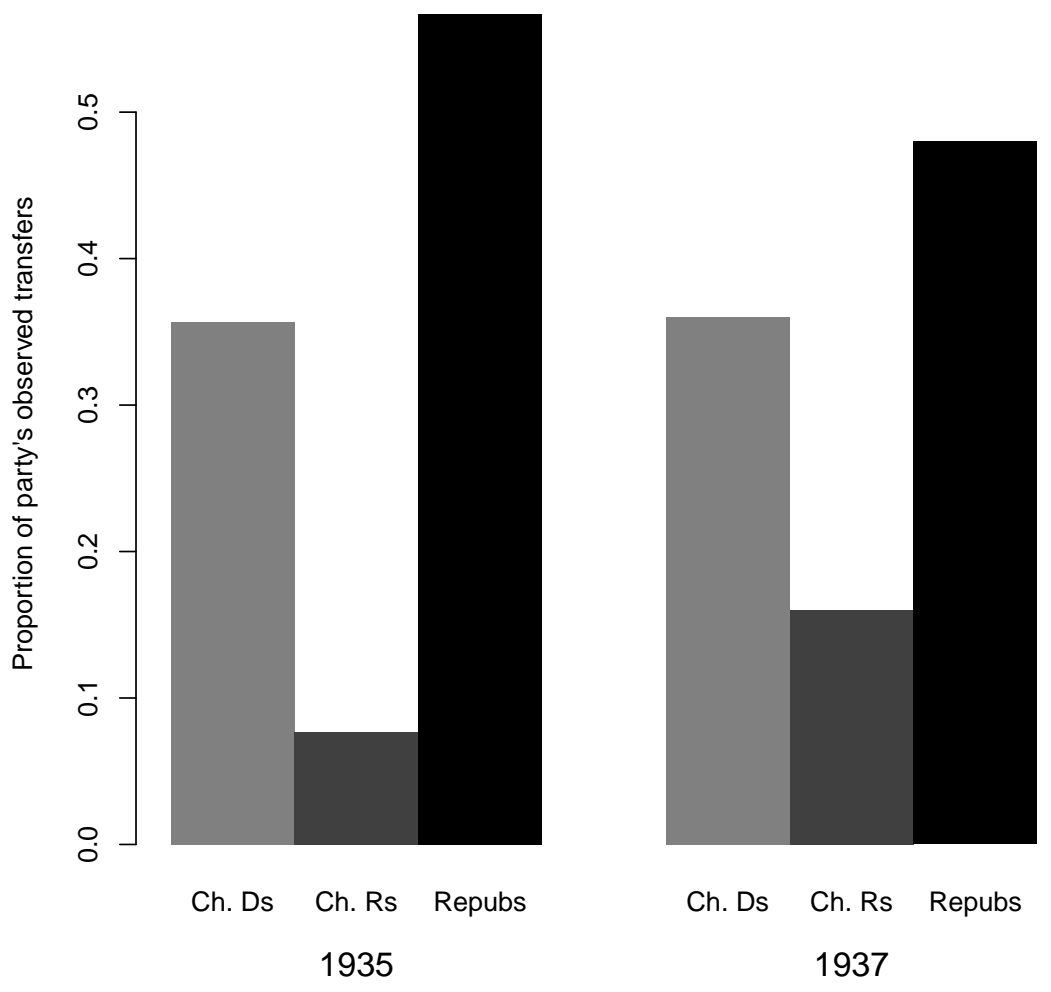

Figure 3: Progressive Democratic transfers favor Republicans and Charter Democrats. Calculated from figures in Results of Elections in Hamilton County.

changes in their alliance with Charter" ran an independent Labor slate. ${ }^{34}$ Although no Laborite won, and although the slate appears to have drawn support from both parties, Charter's majority fell from 6-3 to 5-4. A second labor-driven slate of Roosevelt Democrats broke with Charter in 1937. The combination of labor slates, PDs, and independent candidacies drew 19-21 percent of first-preference votes from 1935-9 (Figure 4). That share was more than enough to deliver a single seat in Cincinnati's PR elections, and given more coordination, left-leaning independents might even have won two seats.

What put an end to labor defection was a deal with the Republicans. In 1938, PD council member Wiley Craig reached his own accord. If Taft sought to distance Charter from 


\section{Elections in Cincinnati: \\ Landslides, volatility, then two-party equilibrium}

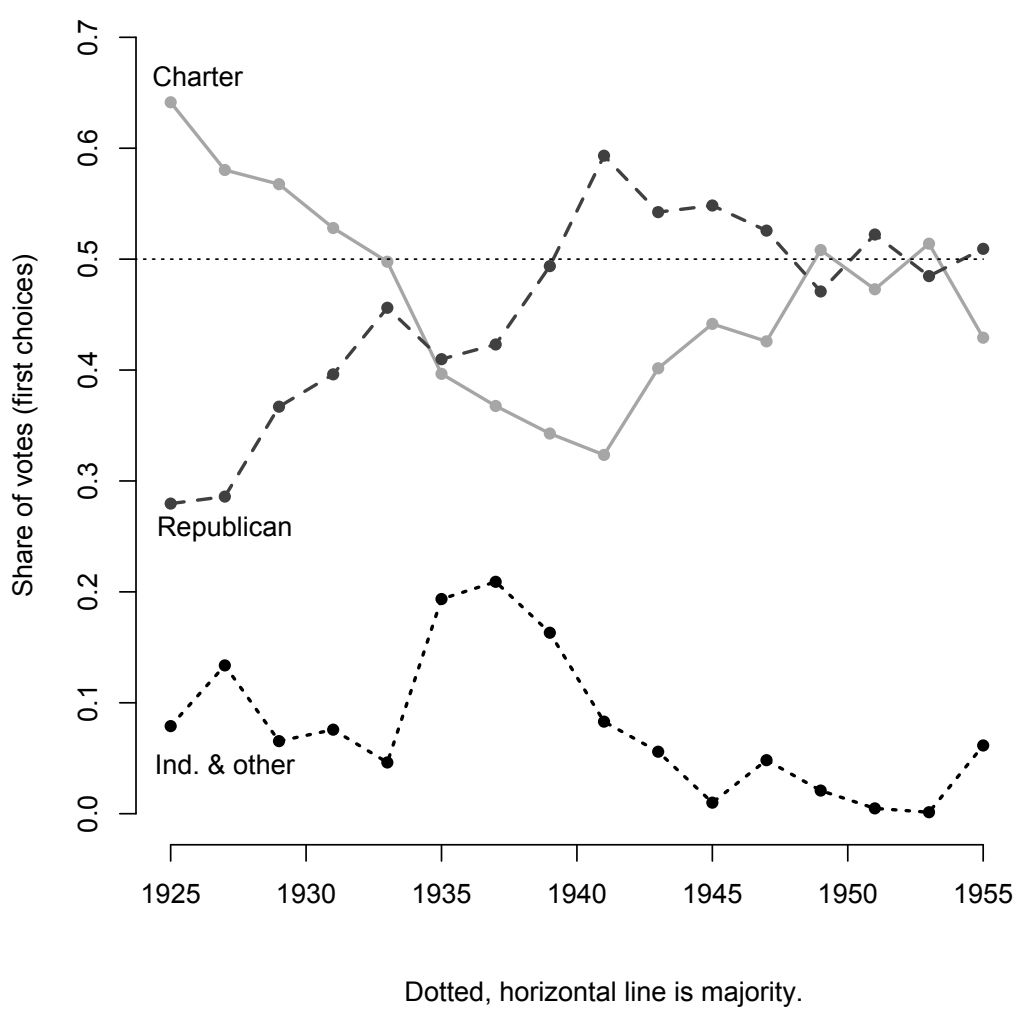

Figure 4: Third-party defections in the 1930s herald a decade of Republican dominance.

Bigelow's redistributive program, Craig wanted to remedy Democrats' "patronage chances" in town. In return for Craig's mayoral vote, Republicans put the president of the Central Labor Council on the Civil Service Commission. ${ }^{35}$ In turn, Craig ran and won as a Republican in 1941 and $1943 .{ }^{36}$

Yet business and labor struck another deal that staved off repeal for most of the 1940s, this one extending to Washington, DC. Federal urban policy, as it came to be known, was Roosevelt's tool to consolidate the Democratic Party in American cities. Its main prongs were the construction of public housing and infrastructure including "highways, bridges, dams, airports, public buildings, sewer and water projects, and other public works." ${ }^{37}$ The policy bundle had two key targets: a Depression-induced housing shortage, then a general 
lack of industrial employment. To these ends, Congress and state governments authorized local bodies to condemn "substandard" buildings, take land, borrow funds, and hire workers. Politically, these New Deal programs were meant to break voters' dependence on big-city machines, turning their allegiance toward the federal Democrats.

In practice, business interests were able to force beneficial compromises, especially as the Conservative Coalition gained influence in Congress. Urban policy would reflect such compromises through the New Deal, Fair Deal, and Eisenhower years. ${ }^{38}$ John Mollenkopf has documented these compromises at length. His account of the 1937 Wagner Housing Act is worth quoting:

One set of forces, led by [Senator Robert F.] Wagner [D-NY] and backed by social workers, housing officials, local affiliates of the Labor Housing Conference, and the AFL [American Federation of Labor], sought to emphasize public or subsidized housing for the broadest possible range of urban residents with only so much emphasis on slum clearance as was necessary to secure sites for this housing...

... Finally, though they liked slum clearance and subsidies for private construction, housing industry lobby groups strongly opposed any kind of public housing program. The politically powerful National Association of Real Estate Boards, the US Building and Loan League, the Chamber of Commerce, and the National Retail Lumber Dealers Association all railed against the idea. ${ }^{39}$

For one contemporary observer, New Deal bipartisanship captured the "issuelessness" of Ohio politics. The Democratic governor during this period $(1944-6,1948-56)$ pursued 
policies "as conservative as those advocated by any of his Republican opponents." Further, "critics in state government also attacked [Frank Lauche's] policy of minimizing expenditures on education and welfare and the investment of substantial sums in highways." 40

Cincinnati's council took its first non-unanimous vote on a Works Progress Administration bond issue on January 19, 1938. It won with all-party support if we include thenProgressive Wiley Craig and the Charter Republicans and Democrats who backed it. ${ }^{41}$ There ensued programs to dam Ohio River tributaries, construct highways, and clear slums. Eventually "slum clearance" would give way to "urban renewal." 42

One bipartisan compromise is worth note. A Charter-dominated City Planning Commission $(\mathrm{CPC})$ in 1941 announced intent to hire experts to write an upcoming metropolitan master plan. Republican majorities refused to fund these consultants until 1944, when the CPC empowered public-private "land commissions" to take land by eminent domain. ${ }^{43}$ Federal policy operated through these bodies in many cities, exacerbating race and class segregation in at least some of them. ${ }^{44}$ Compromises like these characterized the local implementation of federal urban policy throughout the late 1930s and 1940s, during which Republicans held council majorities in Cincinnati.

If labor and developmentalists were willing to cooperate on New Deal policy, why did they not insulate that coalition by repealing PR? Available information suggests labor thought that PR maximized its power to bargain with Republicans. When repeal came up in 1936, 1939, and eventually 1947, labor leaders soul-searched. Last-minute committees set up by some AFL and CIO locals probably saved PR in 1939. Labor-Republican tension came to a head in 1947. Republicans refused to slate AFL candidates that year, and Charter ran an AFL-affiliated Republican. Yet the local AFL supported PR and the Republican slate at 
the same time. Meanwhile, the CIO issued memoranda on the importance of cooperating with business. ${ }^{45} \mathrm{PR}$ allowed labor to play balance-of-power politics.

Labor leaders were not the only partners to bipartisan developmentalism. One important Democrat was eventual Mayor Edward Waldvogel. His pursuit of highway construction from the late 1930s onward earned him the vice mayoralty on Republican watch. Readers familiar with local roads may recall the Waldvogel Memorial Viaduct, which eventually connected downtown streets to Interstate 75 .

\section{Labor sidelined, 1948-53}

By 1947, working arrangements between organized labor and the Republican Party began to fray. In national politics, the National Labor Relations Act (known informally as TaftHartley) rolled back New Deal union protections. In New York City, where PR had been in place for 10 years, state and local Republican leaders abrogated their alliance of convenience with the American Labor Party. ${ }^{46}$

Within Cincinnati, the break with labor centered on controversy over a 1948 Metropolitan Master Plan, much of which involved "slum clearance" and eventually "urban renewal." 47 One key planner was Rollin Everett, a city council Democrat and representative of the CIO. Late in 1948, Everett sponsored a resolution of intent to mandate nondiscrimination in "temporary" public housing. The motion spent more than a month in two different

committees. We do not yet know whether the final report included that language. ${ }^{48}$

Tensions in the labor-Republican coalition had simmered throughout the 1940s, and it became clear that some in the Republican Party wanted a veto-proof council majority. 
Under the city charter, six council votes were needed to override any decision of the planning commission. The earliest attack came on February 2, 1943, when Republicans canceled a "gentlemen's agreement" governing council vacancies. Under that agreement, whenever a council seat became vacant, the party of the departing member would be asked to choose their replacement, regardless of who held the majority. With the Charter Republican Taft off to work in the Roosevelt Administration, the GOP majority appointed Charles W. Weber in his stead. For the first time since 1931, one party held six seats. Republicans would repeat this practice through 1953, whenever a Charter seat became vacant on their watch. Charter Republican Russell Wilson died in December 1946. On January 2, 1947, the Republicans filled his seat with Homer Toms.

Vacancies also let Republicans increase the discipline of their own delegation. In March 1947, freshman Carl Rich filled the seat of long-time Mayor James G. Stewart. ${ }^{49}$ In July of that year, they used their supermajority authorize a referendum on repealing PR. ${ }^{50} \mathrm{In}$ contrast to the razor-thin margins of earlier efforts, repeal lost by 7,592 votes (5 percent).

By the early 1950s, conflict over city planning took the form of a full-blown, McCarthyist witch hunt. ${ }^{51}$ Planning commission newcomers Henry Bettman (C) and Wallace Collett (C) had just hired a new Planning Director, Sydney H. Williams. Copies of an internal FBI report somehow arrived in the office of the City Manager. It identified Williams as exmember of a Marxist study group. Republicans demanded that all three resign. Bettmann did not, but the City Manager, Williams, and Collett all left their posts. ${ }^{52}$

Further, Council's Republican freshmen became increasingly conservative. One was Donald D. Clancy (elected 1951), eventually Mayor and planning commission chairman in the years just after PR's 1957 repeal. Clancy went to Congress in 1961 (R-OH). A statistical 
estimate of his policy conservatism places him among the most loyal Republicans of the $87^{\text {th }}$ Congress (1961-63). ${ }^{53}$ Another freshman, Douglas M. Allen (elected 1949) publicly assailed "Charter-Democrats" for insisting that suburbs pay higher rates for access to city utilities. ${ }^{54}$ Allen, it should be noted, released the FBI report to the local Times-Star. Critics argued he should have addressed it in an executive session of Council..$^{55}$

The following term welcomed a third freshman, William Cody Kelly (elected 1953). An ex-clerk on the planning commission, Kelly was 1954 recipient of the United States Junior Chamber of Commerce Distinguished Service Award. ${ }^{56}$ When Charter moved to set up a housing agency, Kelly tried to merge its functions with highway planning in a Department of Expressways and Urban Renewal. ${ }^{57}$ In later years, Kelly worked for the Goldwater campaign and Republican National Committee Chair Ray Bliss. ${ }^{58}$

The national parties by now had different positions on the housing shortage, and these were manifest in Cincinnati. While the 1952 Democratic Party platform explicitly sanctioned federal funds for public housing under the 1949 Housing Act, the Republican platform spoke in terms of "free enterprise" and "local cooperation." ${ }^{59}$ Within the city, Republican politicians railed against Charter "Trumanism" while Charter planned for government-funded housing projects. ${ }^{60}$

\section{Liberals seize Charter \& labor reacts: the 1950s}

PR faced two more repeal attempts in 1954 and 1957. Both originated in the New Deal wing of the local Democratic Party. The reason is that, while unions had played both sides of the legislative street during the Depression, the early 1950s saw middle-class liberals take 
on that role. Now that Republicans had severed their ties to labor, it was Charter's turn to do the same.

When Mayor Waldvogel died in early 1954, Berry was the only veteran Democrat left in Charter's council delegation. Indeed, he was the only Charter veteran at all. Four new faces joined him in 1954-5. One was Vincent Beckman, Waldvogel's Democratic replacement. Next was John "Jack" Gilligan, the eventual Democratic governor who implemented earnings taxes statewide. Then there was Albert C. Jordan, local president of the CIO-affiliated United Steelworkers. Last was Dorothy "Dot" Dolbey, formerly a Democrat and now the only Charter Republican in council. Figure 2 shows how dramatic was the change in Charter's caucus. November 1953 registered as the single largest wave of legislator replacement in Charter's electoral history.

Berry and the freshman Democrats supported labor initiatives. Several early roll calls had them voting in lock-step with Jordan. The first concerned a labor dispute at Spring Grove Cemetery, then the nation's second-largest. The second was a vote on a bill to guarantee collective bargaining rights in all local industries. Finally, Berry stood alone with Jordan on a vote to publish the latter's CIO affiliation in publicly distributed council minutes. ${ }^{61}$

The trouble was Dorothy "Dot" Dolbey. On each of these votes, this lone Charter Republican crossed over to the regular GOP. According to a local PR critic, Dolbey represented "a politically unidentifiable person whose chief political conviction is that she should be mayor." 62

Sidelining Dolbey would have been difficult for Berry. Both were on the same side of a simmering racial controversy. Dolbey had been a leading member of the Mayor's Friendly Relations Committee, organized in 1943 following riots in Detroit. ${ }^{63}$ Her initiatives included 
Figure 5: Berry (bold "B") straddles a wave of Charter Party replacement.

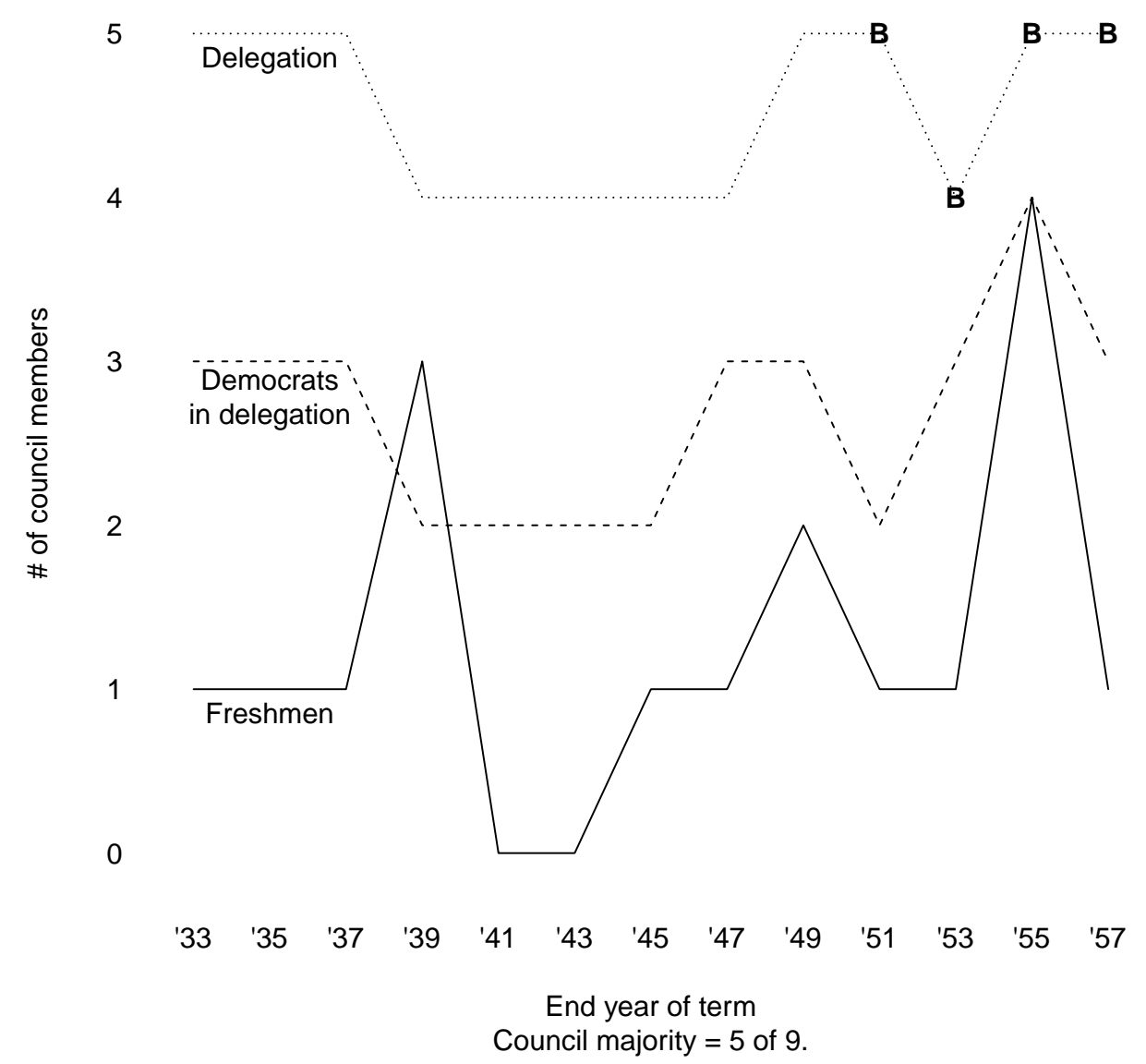

curfews for children under 17 years, a task force on juvenile delinquency, and prohibition on pinball machines then used for petty gambling. If Ralph Straetz is right that "racial hostility" represented "an old ingredient of Cincinnati politics," Dolbey was a valuable ally. ${ }^{64}$

Mayor Waldvogel's death in 1954 gave Dolbey and Jordan another reason to spar. After five months and 16 roll calls to replace Waldvogel, Jordan cast his vote for a veteran organization Republican. Berry backed Dolbey and declined Jordan's nomination, claiming, "If I cannot play first fiddle, I certainly do not want to play second fiddle." Jordan retorted, "It is unwise for the Charter party to insist upon Mrs. Dolbey being mayor. I believe that because 
of this attitude, PR is gone forever and that the Charter party will eventually disappear." 65

One wonders to whom Berry worried about playing second fiddle. It may have been the county Democratic leadership. It may have been the CIO itself. Charter's steering committee officially attributed Jordan's vote to instructions from Al Whitehouse, head of the national AFL-CIO Industrial Union Department (IUD). ${ }^{66}$ Another CIO official, Ben Stoner, was present for the mayoral debacle, apparently giving Jordan permission to violate state CIO policy in not voting for a Democrat. ${ }^{67}$ None of the sitting Democrats were acceptable.

The politics of Fair Employment Practices suggest that inter-Democratic sparring was partly over control of black voters' allegiances. Berry, allegedly a "militant FEPC Negro who has been forgetting the Civil War and switching to the Democrats," 68 excoriated Jordan as a "Johnny-Come-Lately in fair employment efforts." The two had filed competing FEPC ordinances. Jordan called Berry's bill "a cheap, underhanded contrivance to confuse and deceive the Negro population of Cincinnati." 69 The difference between the bills was the severity of penalties for violations. Jordan was on the penalties side, a position with at least some support among Cincinnati blacks. ${ }^{70}$

Berry's support for a penalty-free bill, however, was also a bid for middle-class support. Much as small business chafes at health insurance mandates today, they would have opposed a choice between fines and quota hiring in the mid-1950s.

One last controversy split the unions from Charter. Cincinnati entered 1954 without the funds to cover its budget. One option was to raise the mill rate, which middle-class voters opposed. Council, in fact, had repeatedly tried various means to lower the winning threshold in bond referenda. ${ }^{71}$ A second was to cut city services, which neither unions nor liberals wanted to do. The third was an income tax, and this was the compromise that 
Berry proposed. Jordan so opposed it that he quit Charter immediately. Charter blamed the AFL-CIO: Whitehouse would "break any group, including Charter, that does not accept the Whitehouse position on taxation." ${ }^{72}$ In the 1950s, income taxes were an unpopular way to handle city fiscal crises. ${ }^{73}$ The national CIO called them "viciously regressive." 74

Dolbey defeated Jordan in a recount of the 1955 election, and the unions were without any council seats. Joining her was a second Charter Republican, Charles Phelps Taft, the one who in 1938 had crossed the legislative aisle to prevent Progressive Democrats from picking the mayor. Newspapers had predicted Taft to replace Dolbey in 1955, but 54 percent of Berry's transfer votes flowed to Charter Republicans. ${ }^{75}$ Berry had become the focus of anger at Charter Republicans.

Formally, the Democratic Party defended PR in 1957, but those aligned with the Charter Improvement League (CIL) wanted to purge it. CIL's Democratic leader pointed to example black candidates winning state legislative seats in plurality districts. ${ }^{76}$ This self-described "old-line Democrat" was frustrated with a "lag in expressway construction." 77 He argued the end of PR "would put an end to block-voting and bigotry and return Council to party responsibility." 78 By eliminating PR, CIL would raise the electoral threshold and remove the logic of vote transfers, pushing blacks, labor, and liberals into one disciplined party. CIL filed the requisite signatures early in 1955, and the referendum ordinance got its first reading on March $7 .{ }^{79}$

Days before the 1957 referendum, Whitehouse of the national AFL-CIO traveled to Cincinnati and convened the union locals. They declared PR "a vehicle that permits professional politicians to play both sides of the street." They aimed at no less than "dissolution of the Charter Party." ${ }^{80}$ That the CIO got. In 1957, Democrats again nominated jointly 
with Charter Republicans, not yet sure of the referendum outcome. When Democrats finally withdrew in 1959, they and Charter's rump won two seats each. By 1961, Democrats held three and Charter just one.

\section{Keeping PR requires enforcing party discipline}

Today there is a movement to restore PR in our cities, then expand its use to state and national government. Reformers call PR the "multi-winner form of ranked-choice voting." Their case makes two basic points. First, PR promotes minority representation without resort to creative redistricting. Second, PR promotes the representation of multiple minorities. Seats will go not just to the other major party, but to "independents" in both parties and maybe even some minor parties. Resulting legislatures will reflect the diversity of underlying society.

In making the case for PR, reformers seek to explain why it was so unpopular in the twentieth century. PR survived past 1961 in only one of 24 cities: Cambridge, Massachusetts. The standard line is that minority representation could not survive two reactionary currents: one against racial empowerment, another against the political left. The evidence for this line comes from Cincinnati and New York City. ${ }^{81}$

The trouble is that far more cities used PR than just Cincinnati and New York. In Massachusetts, for example, seven cities had PR elections, and we have no record of Berrylike figures in any of them. We also know of cities that did have colorful figures, did not have PR elections, and saw no efforts to change the voting rules. Consider Bridgeport, Connecticut, where Socialist Jasper McLevy was mayor from 1933-57. 
One common thread runs throughout Cincinnati's PR history: fluid council coalitions. In the span of only three decades, a middle-class Progressive coalition gave way to a tense working arrangement between unions and regular Republicans. That working arrangement then gave way to shaky, new Charter majorities: supportive of racial equality but not able to cohere on labor liberalism. Charter's Progressive Republicans broke with Charter's unions, and the unions fought back.

As implemented in the United States, open-endorsement STV (or what Americans used to call "PR") essentially allowed popular candidates to field multiple lists of their own. Neither the free-list nor Gove systems would have permitted that. By PR's 1957 end in Cincinnati, Charter Republicans were sending votes to regular Republicans, regular Republicans were sending votes to non-Republicans, and Theodore Berry was sending votes to Dorothy Dolbey. This is how one Charter Republican, expected to lose election in 1955, returned to council that November.

Under a normal PR system, Charter Republicans simply might have gone into coalition with the regular Republican Party. What we saw instead was a series of different majorities for different types of legislation: Charter together on most issues, Charter Republicans with regular Republicans on labor issues. These two patterns of council voting mirrored the patterns in vote transfers.

PR produces multi-party legislatures. Making legislation requires a majority. There can be one majority for all legislation or different majorities for different types of bills. When coalitions shift, coalition partners get hurt. No doubt, the 1950s saw volatile movement politics, but we do not need movements to explain PR's end in America. Open-endorsement STV is bad for party discipline. 


\section{Notes}

${ }^{1}$ Stein Rokkan, Citizens, Elections, Parties: Approaches to the Comparative Study of the Processes of Development (Oslo, Norway: Universitetforlaget, 1970); Carles Boix, "Setting the Rules of the Game: The Choice of Electoral Systems in Advanced Democracies," American Political Science Review 93, no. 3 (1999): 609-624; Thomas R. Cusack, Torben Iversen, and David Soskice, "Economic Interests and the Origins of Electoral Systems," American Political Science Review 101, no. 3 (August 2007): 373-391; Ernesto Calvo, "The Competitive Road to Proportional Representation: Partisan Biases and Electoral Regime Change under Increasing Party Competition," World Politics 61, no. 2 (2009): 254-95; Marcus Kreuzer, "Historical Knowledge and Quantitative Analysis: The Case of the Origins of Proportional Representation," American Political Science Review 104, no. 2 (2010): 369-92.

${ }^{2}$ Maurice Duverger, Political Parties: Their Organization and Activity in the Modern State (New York, NY: Wiley, 1954); Rein Taagepera and Matthew S. Shugart, Seats $\&$ Votes: The Effects and Determinants of Electoral Systems (New Haven, CT: Yale University Press, 1989); Gary W. Cox, Making Votes Count: Strategic Coordination in the World's Electoral Systems (Cambridge University Press, 1997); Rein Taagepera, Predicting Party Sizes (Oxford: Oxford University Press, 2007); Yuhui Li and Matthew S. Shugart, "The Seat Product Model of the Effective Number of Parties: A Case for Applied Political Science," Electoral Studies, 2015, doi:10.1016/j.electstud.2015.10.011.

${ }^{3}$ Ronald Rogowski, "Trade and the Variety of Democratic Institutions," International Organization 41, no. 2 (1987): 203-23; Arend Lijphart, Patterns of Democracy: Government Forms and Performance in Thirty-Six Countries (New Haven: Yale University Press, 1999); Torsten Persson and Guido Tabellini, Political Economics: Explaining Economic Policy (Cambridge, MA: MIT Press, 2000); Alberto Alesina and Edward L. Glaeser, Fighting Poverty in the U.S. and Europe: A World of Difference (Oxford, UK: Oxford University Press, 2004); Torben Iversen and David Soskice, "Electoral Institutions and the Politics of Coalitions: Why Some Democracies Redistribute More Than Others," American Political Science Review 100, no. 2 (May 2006): 165-181; Kathleen Bawn and Frances Rosenbluth, "Short versus Long Coalitions: Electoral Accountability and the Size of the Public Sector," American Journal of Political Science 50, no. 2 (2006): 251-65; Adam Bonica et al., "Why Hasn't Democracy Slowed Rising Inequality?," Journal of Economic 
Perspectives 27, no. 3 (2013): 103-24; Michael Becher, "Endogenous Credible Commitment and Party Competition over Redistribution under Alternative Electoral Institutions," American Journal of Political Science Early View (2015), doi:10.1111/ajps.12242; Döring Holger and Philip Manow, "Is Proportional Representation More Favourable to the Left? Electoral Rules and Their Impact on Elections, Parliaments and the Formation of Cabinets," British Journal of Political Science FirstView (April 2016): 1-16, Issn: 1469-2112, doi:10.1017/S0007123415000290, http://journals.cambridge.org/article_S0007123415000290.

${ }^{4}$ Lucas Leeman and Isabela Mares, "The Adoption of Proportional Representation," Journal of Politics 76, no. 2 (April 2014): 461-478; Cusack, Iversen, and Soskice, "Economic Interests and the Origins of Electoral Systems"; Thomas R. Cusack, Torben Iversen, and David Soskice, "Coevolution of Capitalism and Political Representation: The Choice of Electoral Systems," American Political Science Review 104, no. 2 (May 2010): 394-403.

${ }^{5}$ Corrine M. McConnaughy, The Woman Suffrage Movement in America: A Reassessment (New York: Cambridge University Press, 2013).

${ }^{6}$ Amy Bridges and Richard Kronick, "Writing the Rules to Win the Game: The Middle-Class Regimes of Municipal Reformers," Urban Affairs Review 34, no. 5 (May 1999): 691-706; Cheon Geun Choi, Jungah Bae, and Richard C. Feiock, "The Adoption and Abandonment of Council-Manager Government," Public Administration Review 73, no. 5 (2013): 727-736.

${ }^{7}$ Richard S. Childs, The First Fifty Years of the Council-Manager Plan of Municipal Government (New York: National Municipal League, 1965); H. George Frederickson, Gary A. Johnson, and Curtis H. Wood, The Adapted City: Institutional Dynamics and Structural Change (London, UK: M.E. Sharpe, 2004).

${ }^{8}$ Charles Phelps Taft, City Management: The Cincinnati Experience (Port Washington, NY: Kennikat Press, 1971).

${ }^{9}$ Kathleen L. Barber, ed., Proportional Representation and Election Reform in Ohio (Columbus, OH: Ohio State University Press, 1995); Kathleen L. Barber, A Right to Representation: Proportional Election Systems for the Twenty-first Century (Columbus, OH: Ohio State University Press, 2000); Francesco Trebbi, Philippe Aghion, and Alberto Alesina, "Electoral Rules and Minority Representation in U.S. Cities," Quarterly Journal of Economics 123, no. 1 (2008): 325-357. 
${ }^{10}$ Douglas Martin, "Theodore Berry, 94, Civil Rights Pioneer, Dies," New York Times, Oct. 17, 2000. Online at https://nyti.ms/2q3zZEL.

${ }^{11}$ Robert J. Kolesar, "Communism, Race, and the Defeat of Proportional Representation in Cold War America" (Presented at the New England Historical Association Conference, Amherst College. April 1996); Douglas J. Amy, "The Forgotten History of the Single Transferable Vote in the United States," Representation 34, no. 1 (1996): 13-20; Douglas J. Amy, Real Choices / New Voices: How Proportional Representation Elections Could Revitalize American Democracy, 2nd ed. (New York: Columbia University Press, 2002).

${ }^{12}$ Robert J. Kolesar, "PR in Cincinnati: From 'Good Government' to the Politics of Inclusion?," chap. 6 in Proportional Representation and Election Reform in Ohio, ed. Kathleen L. Barber (Ohio State University Press, 1995), 160-208; Robert A. Burnham, "Reform, Politics, and Race in Cincinnati: Proportional Representation and the City Charter Committee, 1924-1959," Journal of Urban History 23, no. 2 (January 1997): $131-163$.

${ }^{13}$ Leon Weaver, "The Rise, Decline, and Resurrection of Proportional Representation in Local Governments in the United States," chap. 8 in Electoral Laws and their Political Consequences, ed. Bernard Grofman and Arend Lijphart (New York, NY: Agathon Press, 1986), 139-153.

${ }^{14}$ John M. Carey and Matthew S. Shugart, "Incentives to Cultivate a Personal Vote: A Rank Ordering of Electoral Formulas," Electoral Studies 14, no. 4 (1995): 417-439.

${ }^{15}$ William H. Gove, "The Relation of the Gove System to Other Methods of Proportional Representation," Proportional Representation Review 2, no. 6 (December 1894): 41-7.

${ }^{16}$ Technically, the vote share needed to win a seat in STV is a Droop quota: $\frac{\text { Total valid votes }}{\text { Seats in district+1 }}+1$.

17 “Office Is Opened By Cincinnati Foes Of PR Balloting," Cincinnati Enquirer, July 3, 1954.

${ }^{18}$ Jack Santucci, "Party Splits, not Progressives: The Origins of Proportional Representation in American Local Government," American Politics Research 45, no. 3 (2017): 494-526, doi:10.1177/1532673X16674774.

${ }^{19}$ Kolesar, "PR in Cincinnati," 167-70.

${ }^{20}$ Ralph A. Straetz, PR Politics in Cincinnati: Thirty-two Years of City Government through Proportional Representation (New York, NY: New York University Press, 1958).

${ }^{21}$ Associated Press, "New Test On Cincinnati Representation System," Daily Reporter, September 30, 
1957.

${ }^{22}$ Richard L. Engstrom, "Cincinnati's 1988 Proportional Representation Initiative," Electoral Studies 9, no. 3 (1990): 219; Burnham, "Reform, Politics, and Race," 152.

${ }^{23}$ Harvard Sitkoff, "Harry Truman and the Election of 1948: The Coming of Age of Civil Rights in American Politics," Journal of Southern History 37, no. 4 (November 1971): 597-616; Brian D. Feinstein and Eric Schickler, "Platforms and Partners: The Civil Rights Realignment Reconsidered," Studies in American Political Development 22 (Spring 2008): 1-31; Eric Schickler, "New Deal Liberalism and Racial Liberalism in the Mass Public, 1937-1968," Perspectives on Politics 11, no. 1 (March 2013): 75-98.

${ }^{24} \mathrm{STV}$ also involves the sequential elimination of last-placed candidates in any vote-counting round that does not produce a winning share. The logic of transfer-sharing here is the same.

${ }^{25}$ Both panels are based on observable transfers (i.e., only those flowing from eliminated candidates or those with surplus votes). Dips in Charter Democratic transfers to Charter for 1929, 1931, 1937, 1941, and 1943 are attributable to two facts. First, Democrats were junior partners in Charter until after World War II. They ran in fewer numbers and tended to win on transfers from Charter Republicans. Witness the zero transfer rates in 1929 and 1931. When Democrats did not win, as in 1937, 1941, and 1943, they made poor first-choice showings ( $\max$ of 2,751 votes) and were eliminated early. These eliminations become the denominators in Charter Democratic transfer rates for these years, so that the graphs visually overstate Democrats' out-of-Charter transfers.

Local-party affiliations of all candidates are drawn from annual issues of Elections in Hamilton County.. Major-party affiliations of Charter candidates come primarily from slate announcements in the Cincinnati Enquirer. When those were unhelpful, I consulted Straetz (PR Politics), Burnham ("Pulling Together for Pluralism"), Kolesar ("PR in Cincinnati"), Enquirer commentaries on the candidates, and http://www. politicalgraveyard.com.

${ }^{26}$ Amy Bridges, Morning Glories: Municipal Reform in the Southwest (Princeton, NJ: Princeton University Press, 1997); Bridges and Kronick, "Writing the Rules to Win the Game: The Middle-Class Regimes of Municipal Reformers."

${ }^{27}$ Kolesar, "PR in Cincinnati," 167. 
${ }^{28}$ Straetz, PR Politics, 156.

${ }^{29}$ Burnham, "Reform, Politics, and Race," 133-7.

${ }^{30}$ Charter endorsed its first African-American candidate, a Democrat, in 1937. Candidates' racial identifications come from slate announcements and commentaries in the Cincinnati Enquirer, 1925-55, supplemented by Straetz (PR Politics, 109-25).

${ }^{31}$ Taylor ("Creating the Metropolis in Black and White," 57-8). Burnham ("The Divided Metropolis: Subdivision Control and the Demise of Comprehensive Metropolitan Planning in Hamilton County, Ohio, 1929-1953," 51) offers a more benign view, arguing that regulation also involved efforts to provide appropriate water and sewer services to "subdivisions for black families."

32 "Political Gossip," Cincinnati Enquirer, October 27, 1929. See also Straetz (PR Politics, 47, 59). The More Homes chairman ran with Republican endorsement in 1929.

${ }^{33}$ Kolesar, "PR in Cincinnati," 177-83.

${ }^{34}$ Straetz, PR Politics, 126.

${ }^{35}$ Ibid., 130.

${ }^{36}$ See Results of Elections in Hamilton County. for 1925-55.

${ }^{37}$ John H. Mollenkopf, The Contested City (Princeton: Princeton University Press, 1983), 65.

${ }^{38}$ Hoffman ("Calling upon the Genius of Private Enterprise") argues that, despite Johnson's brief mandate in 1964, the 1968 Housing and Urban Development Act renewed private-sector advantage in local implementation of federal housing policy.

${ }^{39}$ Mollenkopf, The Contested City, 68-9.

${ }^{40}$ John H. Fenton, Midwest Politics (New York: Holt, Rinehart \& Winston, 1966), 148.

${ }^{41}$ See the City Bulletin for the respective meetings.

${ }^{42}$ Zane L. Miller and Bruce Tucker, "The New Urban Politics: Planning and Development in Cincinnati, 1954-1988," chap. 5 in Snowbelt Cities: Metropolitan Politics in the Northeast and Midwest since World War II, ed. Richard M. Bernard (Bloomington and Indianapolis, IN: Indiana University Press, 1990), 91108; Burnham, "Pulling Together for Pluralism"; Charles F. Casey-Leininger, "Making the Second Ghetto in Cincinnati: Avondale, 1925-70," in Race and the City: Work, Community, and Protest in Cincinnati, 
1820-1970, ed. Henry Louis Taylor (Urbana and Chicago: University of Illinois Press, 1993), 232-57.

${ }^{43}$ Burnham, "Pulling Together for Pluralism," 191-7.

${ }^{44}$ Philip H. Hill, "Recent Slum Clearance and Urban Redevelopment Laws," Washington and Lee Law Review 9, no. 2 (1952): 173-88; Kevin Fox Gotham, "A City without Slums: Urban Renewal, Public Housing, and Downtown Revitalization in Kansas City, Missouri," American Journal of Economics and Sociology 60, no. 1 (2001): 285-315.

${ }^{45}$ Straetz, PR Politics, 126-54.

${ }^{46}$ Belle Zeller and Hugh A. Bone, "The Repeal of PR in New York City: Ten Years in Retrospect," American Political Science Review 42, no. 6 (December 1948): 1127-48.

${ }^{47}$ See weekly issues of the City Bulletin for the 1940s to observe the shift in terminology.

${ }^{48}$ City Bulletin for November 3, November 10, and December 8, 1948. As of this article's date, I await fulfillment of a public records request (January 5, 2016) for the final report.

${ }^{49}$ City Bulletin for March 5, 1947.

${ }^{50}$ City Bulletin for July 7, 1947.

${ }^{51}$ Wallace T. Collett, McCarthyism in Cincinnati: The Bettman-Collett Affair (Rosemont, PA: Selfpublished, 2002).

${ }^{52}$ Straetz, PR Politics, 206.

${ }^{53}$ Technically speaking, Clancy's common-space, first-dimension DW-NOMINATE score in the $87^{\text {th }}$ Congress (1961-63) is 0.414. See ftp://voteview.com/junkord/HANDSL01113C20_NOBSSE.DAT for common-space DW-NOMINATE scores. Downloaded August 5, 2015.

${ }^{54}$ City Bulletin for October 21, 1952.

${ }^{55}$ Ibid., 210.

${ }^{56}$ Kenneth E. Gray, A Report on Politics in Cincinnati, technical report (Cambridge, MA: Joint Center for Urban Studies of the Massachusetts Institute of Technology and Harvard University, 1959), II-14.

${ }^{57}$ Straetz, PR Politics, 195.

${ }^{58}$ Howard Wilkinson, "City greeted Goldwater enthusiastically in '64", Cincinnati Enquirer, May 30, 1998;

"William Kelly, served on Council," Cincinnati Post, April 9, 1997. 
${ }^{59}$ Platforms available from the American Presidency Project. Online at http://www.presidency.ucsb. edu. Downloaded January 11, 2016.

${ }^{60}$ Gray, A Report on Politics in Cincinnati, VI-6; Straetz, PR Politics, 13.

${ }^{61}$ See the City Bulletin for December 23, 1953.

${ }^{62}$ C.V. Anderson, "Charter Trots Out Cox, Hynicka Ghosts To Scare Voters, Businessman Says; But PR Is Real Bogey For City, He Adds," Cincinnati Enquirer, October 31, 1954, p. 6. See also Straetz (PR Politics, $25)$.

${ }^{63}$ Robert A. Burnham, "The Mayor's Friendly Relations Committee: Cultural Pluralism and the Struggle for Black Advancement," in Race and the City: Work, Community, and Protest in Cincinnati, 1820-1970, ed. Henry Louis Taylor (Urbana and Chicago: University of Illinois Press, 1993), 259.

${ }^{64}$ Straetz, PR Politics, xi.

${ }^{65}$ Gilbert Sands, "Rich Elected Mayor By Jordan Switch; Four Charterites Back Dolbey To End," Cincinnati Enquirer, November 11, 1954.

66 "Jordan Fire Still on Berry," Cincinnati Enquirer, November 12, 1954.

${ }^{67}$ Sands, "Rich Elected Mayor By Jordan Switch"; "Elusive Mayoralty," Cincinnati Enquirer, June 11, 1954.

${ }^{68}$ Brady Black, "Significant Points Abound in City Election; If Republicans Elect Five, Who'll They Be?," Cincinnati Enquirer, November 3, 1953

69 "City FEP Ordinance Is Defeated After Stormy Council Debate," Cincinnati Enquirer, July 8, 1955.

${ }^{70}$ Black, "Significant Points Abound In City Election"; "Men And Issues On Ballot," Cincinnati Enquirer, October 24, 1955.

${ }^{71}$ See, for example, the City Bulletin for November 23, 1958 and December 18, 1940; then a summary of bond referenda, 1940-51, in Gray (A Report on Politics in Cincinnati).

72 "Jordan Quits Charterites in Council; Party Raps Him For Selfish Interests," Cincinnati Enquirer, February 26, 1954.

${ }^{73}$ Robert Alan Sigafoos, The Municipal Income Tax: Its History and Problems (Chicago: Public Information Service, 1955). 
${ }^{74}$ Norman I. Gelman, "Local Income Taxes," in Editorial Research Reports 1958, vol. 2 (Washington, DC: CQ Press, 1958), 913-32.

${ }^{75}$ A. M. Forkner, "Same Council Line-Up Predicted For '56, With Taft Replacing Dorothy N. Dolbey," Cincinnati Enquirer, September 5, 1955. Vote transfers are calculated from Elections in Hamilton County for 1955 .

${ }^{76}$ Straetz, PR Politics, 10-12, 27.

77 "Blast Fired By Charter Foe," Cincinnati Enquirer, August 6, 1957.

78 "Office Is Opened By Cincinnati Foes Of PR Balloting," Cincinnati Enquirer, July 3, 1954.

${ }^{79}$ City Bulletin for March 7, 1955.

${ }^{80}$ Michael Maloney, "Steel Worker Leaders Rap PR, Urge Its Defeat In Election; Charter Scored For Wage Tax," Cincinnati Enquirer, September 18, 1957.

${ }^{81}$ FairVote, "Ranked Choice Voting for City Councils at the Turn of the Century." http://www.fairvote . org/fair_representation\#\#fair_voting_in_the_united_states. Accessed May 17, 2017.

\section{References}

Alesina, Alberto, and Edward L. Glaeser. Fighting Poverty in the U.S. and Europe: A World of Difference. Oxford, UK: Oxford University Press, 2004.

Amy, Douglas J. Real Choices / New Voices: How Proportional Representation Elections Could Revitalize American Democracy. 2nd ed. New York: Columbia University Press, 2002.

— "The Forgotten History of the Single Transferable Vote in the United States." Representation 34, no. 1 (1996): 13-20. 
Barber, Kathleen L. A Right to Representation: Proportional Election Systems for the Twentyfirst Century. Columbus, OH: Ohio State University Press, 2000.

ed. Proportional Representation and Election Reform in Ohio. Columbus, OH: Ohio State University Press, 1995.

Bawn, Kathleen, and Frances Rosenbluth. "Short versus Long Coalitions: Electoral Accountability and the Size of the Public Sector." American Journal of Political Science 50, no. 2 (2006): 251-65.

Becher, Michael. "Endogenous Credible Commitment and Party Competition over Redistribution under Alternative Electoral Institutions." American Journal of Political Science Early View (2015). doi:10.1111/ajps.12242.

Boix, Carles. "Setting the Rules of the Game: The Choice of Electoral Systems in Advanced Democracies." American Political Science Review 93, no. 3 (1999): 609-624.

Bonica, Adam, Nolan McCarty, Keith T. Poole, and Howard Rosenthal. "Why Hasn't Democracy Slowed Rising Inequality?" Journal of Economic Perspectives 27, no. 3 (2013): 10324.

Bridges, Amy. Morning Glories: Municipal Reform in the Southwest. Princeton, NJ: Princeton University Press, 1997.

Bridges, Amy, and Richard Kronick. "Writing the Rules to Win the Game: The Middle-Class Regimes of Municipal Reformers." Urban Affairs Review 34, no. 5 (May 1999): 691-706.

Burnham, Robert A. "Pulling Together for Pluralism: Politics, Planning, and Government in Cincinnati, 1924-1959." PhD diss., University of Cincinnati, 1990. 
Burnham, Robert A. "Reform, Politics, and Race in Cincinnati: Proportional Representation and the City Charter Committee, 1924-1959." Journal of Urban History 23, no. 2 (January 1997): 131-163.

—. "The Divided Metropolis: Subdivision Control and the Demise of Comprehensive Metropolitan Planning in Hamilton County, Ohio, 1929-1953." Planning Perspectives 6 (1 1991).

—. "The Mayor's Friendly Relations Committee: Cultural Pluralism and the Struggle for Black Advancement." In Race and the City: Work, Community, and Protest in Cincinnati, 1820-1970, edited by Henry Louis Taylor, 258-79. Urbana and Chicago: University of Illinois Press, 1993.

Calvo, Ernesto. "The Competitive Road to Proportional Representation: Partisan Biases and Electoral Regime Change under Increasing Party Competition." World Politics 61, no. 2 (2009): 254-95.

Carey, John M., and Matthew S. Shugart. "Incentives to Cultivate a Personal Vote: A Rank Ordering of Electoral Formulas." Electoral Studies 14, no. 4 (1995): 417-439.

Casey-Leininger, Charles F. "Making the Second Ghetto in Cincinnati: Avondale, 1925-70." In Race and the City: Work, Community, and Protest in Cincinnati, 1820-1970, edited by Henry Louis Taylor, 232-57. Urbana and Chicago: University of Illinois Press, 1993.

Childs, Richard S. The First Fifty Years of the Council-Manager Plan of Municipal Government. New York: National Municipal League, 1965. 
Choi, Cheon Geun, Jungah Bae, and Richard C. Feiock. "The Adoption and Abandonment of Council-Manager Government." Public Administration Review 73, no. 5 (2013): 727736.

Collett, Wallace T. McCarthyism in Cincinnati: The Bettman-Collett Affair. Rosemont, PA: Self-published, 2002.

Cox, Gary W. Making Votes Count: Strategic Coordination in the World's Electoral Systems. Cambridge University Press, 1997.

Cusack, Thomas R., Torben Iversen, and David Soskice. "Coevolution of Capitalism and Political Representation: The Choice of Electoral Systems." American Political Science Review 104, no. 2 (May 2010): 394-403.

—. "Economic Interests and the Origins of Electoral Systems." American Political Science Review 101, no. 3 (August 2007): 373-391.

Duverger, Maurice. Political Parties: Their Organization and Activity in the Modern State. New York, NY: Wiley, 1954.

Engstrom, Richard L. "Cincinnati's 1988 Proportional Representation Initiative." Electoral Studies 9, no. 3 (1990): 217-225.

Feinstein, Brian D., and Eric Schickler. "Platforms and Partners: The Civil Rights Realignment Reconsidered." Studies in American Political Development 22 (Spring 2008): 131.

Fenton, John H. Midwest Politics. New York: Holt, Rinehart \& Winston, 1966. 
Frederickson, H. George, Gary A. Johnson, and Curtis H. Wood. The Adapted City: Institutional Dynamics and Structural Change. London, UK: M.E. Sharpe, 2004.

Gelman, Norman I. "Local Income Taxes." In Editorial Research Reports 1958, 2:913-32. Washington, DC: CQ Press, 1958.

Gotham, Kevin Fox. "A City without Slums: Urban Renewal, Public Housing, and Downtown Revitalization in Kansas City, Missouri." American Journal of Economics and Sociology 60, no. 1 (2001): 285-315.

Gove, William H. "The Relation of the Gove System to Other Methods of Proportional Representation." Proportional Representation Review 2, no. 6 (December 1894): 41-7.

Gray, Kenneth E. A Report on Politics in Cincinnati. Technical report. Cambridge, MA: Joint Center for Urban Studies of the Massachusetts Institute of Technology and Harvard University, 1959.

Hill, Philip H. "Recent Slum Clearance and Urban Redevelopment Laws." Washington and Lee Law Review 9, no. 2 (1952): 173-88.

Hoffman, Alexander von. "Calling upon the Genius of Private Enterprise: The Housing and Urban Development Act of 1968 and the Liberal Turn to Public-Private Partnerships." Studies in American Political Development 27, no. 2 (2013): 165-94. 
Holger, Döring, and Philip Manow. "Is Proportional Representation More Favourable to the Left? Electoral Rules and Their Impact on Elections, Parliaments and the Formation of Cabinets." British Journal of Political Science FirstView (April 2016): 1-16. ISSN: 1469-2112. doi:10 . 1017/S0007123415000290. http : / / journals . cambridge . org / article_S0007123415000290.

Iversen, Torben, and David Soskice. "Electoral Institutions and the Politics of Coalitions: Why Some Democracies Redistribute More Than Others." American Political Science Review 100, no. 2 (May 2006): 165-181.

Kolesar, Robert J. "Communism, Race, and the Defeat of Proportional Representation in Cold War America." Presented at the New England Historical Association Conference, Amherst College. April 1996.

—_. "PR in Cincinnati: From 'Good Government' to the Politics of Inclusion?" Chap. 6 in Proportional Representation and Election Reform in Ohio, edited by Kathleen L. Barber, 160-208. Ohio State University Press, 1995.

Kreuzer, Marcus. "Historical Knowledge and Quantitative Analysis: The Case of the Origins of Proportional Representation." American Political Science Review 104, no. 2 (2010): $369-92$.

Leeman, Lucas, and Isabela Mares. "The Adoption of Proportional Representation." Journal of Politics 76, no. 2 (April 2014): 461-478. 
Li, Yuhui, and Matthew S. Shugart. "The Seat Product Model of the Effective Number of Parties: A Case for Applied Political Science." Electoral Studies, 2015. doi:10.1016/j . electstud.2015.10.011.

Lijphart, Arend. Patterns of Democracy: Government Forms and Performance in Thirty-Six Countries. New Haven: Yale University Press, 1999.

McConnaughy, Corrine M. The Woman Suffrage Movement in America: A Reassessment. New York: Cambridge University Press, 2013.

Miller, Zane L., and Bruce Tucker. "The New Urban Politics: Planning and Development in Cincinnati, 1954-1988." Chap. 5 in Snowbelt Cities: Metropolitan Politics in the Northeast and Midwest since World War II, edited by Richard M. Bernard, 91-108. Bloomington and Indianapolis, IN: Indiana University Press, 1990.

Mollenkopf, John H. The Contested City. Princeton: Princeton University Press, 1983.

Persson, Torsten, and Guido Tabellini. Political Economics: Explaining Economic Policy. Cambridge, MA: MIT Press, 2000.

Rogowski, Ronald. "Trade and the Variety of Democratic Institutions." International Organization 41, no. 2 (1987): 203-23.

Rokkan, Stein. Citizens, Elections, Parties: Approaches to the Comparative Study of the Processes of Development. Oslo, Norway: Universitetforlaget, 1970.

Santucci, Jack. "Party Splits, not Progressives: The Origins of Proportional Representation in American Local Government." American Politics Research 45, no. 3 (2017): 494-526. doi:10.1177/1532673X16674774. 
Schickler, Eric. "New Deal Liberalism and Racial Liberalism in the Mass Public, 1937-1968." Perspectives on Politics 11, no. 1 (March 2013): 75-98.

Sigafoos, Robert Alan. The Municipal Income Tax: Its History and Problems. Chicago: Public Information Service, 1955.

Sitkoff, Harvard. "Harry Truman and the Election of 1948: The Coming of Age of Civil Rights in American Politics." Journal of Southern History 37, no. 4 (November 1971): $597-616$

Straetz, Ralph A. PR Politics in Cincinnati: Thirty-two Years of City Government through Proportional Representation. New York, NY: New York University Press, 1958.

Taagepera, Rein. Predicting Party Sizes. Oxford: Oxford University Press, 2007.

Taagepera, Rein, and Matthew S. Shugart. Seats \&f Votes: The Effects and Determinants of Electoral Systems. New Haven, CT: Yale University Press, 1989.

Taft, Charles Phelps. City Management: The Cincinnati Experience. Port Washington, NY: Kennikat Press, 1971.

Taylor, Henry Louis. "Creating the Metropolis in Black and White: Black Suburbanization and the Planning Movemement in Cincinnati, 1900-1950." Chap. 2 in Historical Roots of the Urban Crisis: African Americans in the Industrial City, 1900-1950, edited by Henry Louis Taylor and Walter Hill, 51-72. New York \& London: Garland/Taylor \& Francis, 2000. 
Trebbi, Francesco, Philippe Aghion, and Alberto Alesina. "Electoral Rules and Minority Representation in U.S. Cities." Quarterly Journal of Economics 123, no. 1 (2008): 325357.

Weaver, Leon. "The Rise, Decline, and Resurrection of Proportional Representation in Local Governments in the United States." Chap. 8 in Electoral Laws and their Political Consequences, edited by Bernard Grofman and Arend Lijphart, 139-153. New York, NY: Agathon Press, 1986.

Zeller, Belle, and Hugh A. Bone. "The Repeal of PR in New York City: Ten Years in Retrospect." American Political Science Review 42, no. 6 (December 1948): 1127-48. 